\title{
SOSIO KULTURAL MASYARAKAT DAERAH TEPIAN SUNGAI KAPUAS TANJUNG HILIR TERKAIT STUNTING
}

\section{Socio-Cultural Community Of Kapuas Tanjung Hilir River Banks Related To Stunting}

\section{Desi $^{\text {I* }}$}

Ismi Trihardiani ${ }^{2}$

*IPoltekkes Kemenkes

Pontianak I, Pontianak,

Kalimantan Barat, Indonesia

2Poltekkes Kemenkes

Pontianak 2, Pontianak,

Kalimantan Barat, Indonesia

*email: desigizi77@gmail.com

Kata Kunci:

Sosio Kultural

Sungai Kapuas

Stunting

Keywords:

Socio Cultural

Kapuas River

Stunting

\begin{abstract}
Abstrak
Terjadinya stunting pada balita sering kali tidak disadari, dan setelah dua tahun baru terlihat ternyata balita tersebut pendek. Masalah gizi yang kronis pada balita disebabkan oleh asupan gizi yang kurang dalam waktu yang cukup lama akibat orang tua/keluarga tidak tahu atau belum sadar untuk memberikan makanan yang sesuai dengan kebutuhan gizi anaknya. Tujuan penelitian ini adalah untuk memberikan gambaran tentang sosio kultural masyarakat yang membentuk pemahaman ibu balita tentang stunting, pola konsumsi, pola asuh dan higienis pribadi dan lingkungan daerah tepian sungai kapuas Tanjung Hilir Kota Pontianak. Metode penelitian adalah Penelitian Kualitatif dengan menggunakan desain penelitian Deskriftif. Sampel dalam penelitian ini 40 Balita usia 24-59 bulan. Teknik pengambilan sampel menggunakan metode purposive sampling, Analisis data dilakukan secara deskriptif. Hasil penelitian didapat pola asuh pada pada balita status gizi normal dan dan status gizi stunting memiliki pola asuh yang sama. Pemberian makan anak dalam sehari kurang dari tiga kali sehari pada balita status gizi stunting. Penilaian sanitasi lingkungan atau kebersihan lingkungan di wilayah Tepian Sungai Kapuas Tanjung Hilir, menunjukkan lingkungan yang tidak sehat Kesimpulan Adanya perbedaan pemaknaan yang membentuk pemahaman ibu tentang stunting, pola konsumsi, pola asuh dan higienis pribadi dan lingkungan di wilayah Tepian Sungai Kapuas Tanjung Hilir.
\end{abstract}

(C) year The Authors. Published by Institute for Research and Community Services Universitas Muhammadiyah Palangkaraya. This is Open Access article under the CC-BY-SA License (http://creativecommons.org/licenses/by-sa/4.0/). DOI: https://doi.org//0.33084/jsm.vxix.xxx.

\section{PENDAHULUAN}

Kejadian balita pendek (stunting) dilndonesia menempati urutan ke-5 dunia. Sekitar 5 juta dari 12 juta balita $(38,6 \%)$ di Indonesia memiliki tinggi badan di bawah rata-rata tinggi badan balita di dunia. Data riset kesehatan dasar tahun 2018 bahwa status balita balita pendek sekitar 30,85\%. Data Riset Kesehatan Dasar
(Riskesdas) tahun 2013 memperlihatkan bahwa status gizi balita pendek di Indonesia adalah 37,2\%. Persentase tersebut relatif menunjukkan perbaikan jika dibandingkan dengan data Riskesdas tahun 2010 (35,6\%) dan tahun 2007 (36,8\%) (Kementerian Kesehatan RI, 2010; Kementerian Kesehatan RI, 2013; Kementerian Kesehatan RI, 2018). 
Terjadinya stunting pada balita sering kali tidak disadari, dan setelah dua tahun baru terlihat ternyata balita tersebut pendek. Masalah gizi yang kronis pada balita disebabkan oleh asupan gizi yang kurang dalam waktu yang cukup lama akibat orang tua/keluarga tidak tahu atau belum sadar untuk memberikan makanan yang sesuai dengan kebutuhan gizi anaknya. Data Riskesdas tahun 2010 menunjukkan bahwa ada 21,5\% balita usia 2 - 4 tahun yang mengonsumsi energi di bawah kebutuhan minimal, dan $16 \%$ yang mengonsumsi protein di bawah kebutuhan minimal (Kementerian Kesehatan RI, 2010). Bila hal ini berlangsung dalam waktu lama, maka akan mengganggu pertumbuhan berat dan tinggi badan balita.

Pada ibu hamil juga terdapat $44,4 \%$ yang mengonsumsi energi di bawah kebutuhan minimal dan 49,5\% wanita hamil yang mengonsumsi protein di bawah kebutuhan minimal yang berdampak pada terhambatnya pertumbuhan janin yang dikandungnya (Kementerian Kesehatan RI, 2010).

Program pemerintah dalam penanggulangan masalah gizi pada balita sudah cukup banyak dan terstruktur. Namun, pada kenyataannya, kasus kejadian balita stunting masih banyak dijumpai pada masyarakat dengan karakteristik sosial budaya ekonomi di level manapun. Bagaimana stunting dan masalah gizi pada balita bisa terjadi. Hal ini bisa dikaitkan dengan bagaimana masyarakat itu memberi pemaknaan tentang sehat/sakit pada balita, stunting, pola konsumsi, pola asuh dan higienis pribadi dan lingkungan. Pada komunitas budaya, makna terkonstruksi secara sosial. Pengetahuan dibangun dalam komunitas dan dimaknai oleh individu sehingga membentuk pemahaman yang diyakini sebagai nilai yang ada dalam sebuah komunitas. Hal tersebut bisa terjadi beda makna antara komunitas satu dengan yang lain. Ketika balita pendek (stunting) oleh masyarakat dipandang bukan sebagai masalah dalam perkembangan kesehatan balita, maka prioritas dalam pola pengasuhan bisa menjadi berbeda dalam pemenuhan kebutuhan gizi balita (Kalsum dan Jahari, 20I5).

Adanya perbedaan pemaknaan ini perlu dilakukan penelitian tentang profil sosio kultural masyarakat yang membentuk pemahaman ibu tentang stunting, pola konsumsi, pola asuh dan higienis pribadi dan lingkungan.

\section{METODOLOGI}

\section{Jenis Penelitian}

Jenis penelitian adalah Penelitian Kualitatif dengan menggunakan desain penelitian Deskriftif, yaitu kajian pada fokus tertentu sehingga memperoleh informasi yang mendalam, sehingga saat interprestasi dapat menggambarkan fenomena yang ditemui dilapangan.

\section{Lokasi dan Waktu Penelitian}

Penelitian ini dilakukan kelurahan Tanjung Hilir kecamatan Pontianak Timur Kota Pontianak Kalimantan Barat.

\section{Populasi dan Sampel}

Populasi dalam penelitian ini adalah balita usia 24-59 bulan berjumlah 84 orang. Sampel dalam penelitian ini adalah 40 balita. Teknik pengambilan sampel menggunakan metode purposive sampling.

\section{Pengumpulan Data}

Pengumpulan data merupakan hasil pengukuran tinggi badan dan berat badan pada balita diwilayah Tanjung Hilir. Hasil pengukuran kemudian untuk menentukan pemilihan sampel. Pengumpulan data dilakukan dengan Melakukan observasi langsung, dan wawancara menggunakan kuesioner kepada ibu yang mempunyai balita. Variabel penelitian ini meliputi: karakteristik orang tua, karakteristik sampel, pola konsumsi, pola asuh, higienis pribadi dan lingkungan.

\section{Pengolahan dan Analisis Data}

Analisis data dilakukan secara deskriptif dengan mendiskripsikan atau menggambarkan distribusi frekuensi untuk semua variabel. 


\section{HASIL DAN PEMBAHASAN}

\section{HASIL}

\section{Karakteristik Orang Tua Balita}

Jumlah sampel penelitian sebanyak 40 ayah balita. Persentase tertinggi tingkat pendidikan ayah adalah tamat SMP yaitu 35,0\%. Hasil penelitian menunjukkan ayah balita mempunyai pekerjaan terbanyak adalah buruh sebesar $47,5 \%$. Sedangkan rentang umur ayah balita berada pada usia $31-35$ tahun sebesar $27,5 \%$.

Total ibu balita yang menjadi sampel penelitian adalah 40 ibu balita. Tingkat pendidikan ibu balita terbanyak berada pada tingkat pendidikan SMA yaitu $37,5 \%$. Jenis pekerjaan ibu balita terbanyak jenis pekerjaan ibu rumah tangga sebesar $90,0 \%$. Sedangkan usia ibu balita berada direntang 26-30 tahun sebanyak 37,5\%. Distribusi Karakteristik Orang Tua Balita Di Tanjung Hilir dapat dilihat pada tabel I.

Tabel I. Karakteristik Orang Tua Balita Di Tanjung Hilir Tahun 2020

\begin{tabular}{|c|c|c|c|c|}
\hline Karakteristik & \multicolumn{2}{|c|}{ Ayah } & \multicolumn{2}{|c|}{ Ibu } \\
\hline Pendidikan & $n$ & $\%$ & $\mathrm{n}$ & $\%$ \\
\hline SD & 13 & 32,5 & 10 & 25,0 \\
\hline SMP & 14 & 35,0 & 12 & 30,0 \\
\hline SMA & 10 & 25,0 & 15 & 37,5 \\
\hline Perguruan Tinggi & 3 & 7,5 & 3 & 7,5 \\
\hline \multicolumn{5}{|l|}{ Jenis Pekerjaan } \\
\hline Buruh & 19 & 47,5 & 0 & 0,0 \\
\hline Guru & I & 2,5 & I & 2,5 \\
\hline Honor Swasta & 10 & 25,0 & 2 & 5,0 \\
\hline Pedagang & 2 & 5,0 & 0 & 0,0 \\
\hline Wiraswasta & 7 & 17,5 & 0 & 0,0 \\
\hline Mahasiswa & I & 2,5 & I & 2,5 \\
\hline Ibu Rumah Tangga & 0 & 0,0 & 36 & 90,0 \\
\hline \multicolumn{5}{|l|}{ Usia } \\
\hline $20-25$ & 5 & 12,5 & 6 & 15,0 \\
\hline $26-30$ & 9 & 22,5 & 15 & 37,5 \\
\hline $31-35$ & II & 27,5 & 10 & 25,0 \\
\hline $36-40$ & 8 & 20,0 & 4 & 10,0 \\
\hline$>40$ & 7 & 17,5 & 5 & 12,5 \\
\hline
\end{tabular}

\section{Karakteristik Balita Di Tanjung Hilir}

Jenis kelamin balita dalam penelitian ini menunjukkan sebagian besar jenis kelamin perempuan sebesar 65,0

\%. Berat Badan lahir balita dalam penelitian ini dapat dijelaskan bahwa berat badan lahir balita $\geq 2500$ gram mempunyai persentase tertinggi sebesar $92,5 \%$. Panjang badan lahir dalam penelitian ini menunjukkan karakteristik balita berdasarkan panjang badan lahir balita $\geq 48 \mathrm{~cm}$ persentase sebesar 75,0\%. Distribusi Karakteristik Balita Di Tanjung Hilir dapat dilihat pada tabel II.

Tabel II. Karakteristik Balita Di Tanjung Hilir Tahun 2020

\begin{tabular}{lcc}
\hline \multicolumn{1}{c}{ Karakteristik } & \multicolumn{2}{c}{ Balita } \\
\hline \multicolumn{1}{c}{ Jenis Kelamin } & $\mathrm{n}$ & $\%$ \\
\hline Laki-laki & 14 & 35,0 \\
\multicolumn{1}{c}{ Perempuan } & 26 & 65,0 \\
\hline \multicolumn{2}{c}{ Berat Badan Lahir } & \\
\hline$<2500$ gram & 3 & 7,5 \\
\hline$\geq 2500$ gram & 37 & 92,5 \\
\hline \multicolumn{1}{c}{ Panjang Badan Lahir } & & \\
\hline$<48 \mathrm{~cm}$ & 10 & 25,0 \\
\hline$\geq 48 \mathrm{~cm}$ & 30 & 75,0 \\
\hline
\end{tabular}

\section{Pola Asuh}

Faktor pola asuh terkait dengan riwayat pemberian Asi Ekslusif adalah sebagai berikut:

Tabel III. Pemberian Air Susu Ibu Yang Pertama Kali Keluar (Kolostrum)

\begin{tabular}{|c|c|c|c|c|}
\hline \multirow{2}{*}{$\begin{array}{l}\text { Pemberian } \\
\text { Kolostrum }\end{array}$} & \multicolumn{2}{|c|}{ Normal } & \multicolumn{2}{|c|}{ Stunting } \\
\hline & $\mathrm{n}$ & $\%$ & $n$ & $\%$ \\
\hline Ya & 16 & 80,0 & 16 & 80,0 \\
\hline Tidak & 4 & 20,0 & 4 & 20,0 \\
\hline Jumlah & 20 & 100 & 20 & 100 \\
\hline
\end{tabular}

Pemberian ASI pertama kali keluar (kolostrum) dalam penelitian ini bahwa baik balita status gizi normal dan balita status gizi stunting sebagian besar memberikan kolostrum pada bayi yang baru lahir dengan persentase sebesar $80,0 \%$.

Proses memberikan ASI sesegera mungkin dimulai dengan inisiasi menyusui dini artinya lbu akan memberikan tetesan ASI pertama kali langsung untuk bayi. Berdasarkan hasil penelitian maka diperoleh sebagai berikut:

Tabel IV. Ibu Yang Melakukan Perangsangan Inisiasi Menyusu Dini (IMD) 


\begin{tabular}{|c|c|c|c|c|}
\hline \multirow{3}{*}{$\begin{array}{c}\text { Dalam Beberapa Jam } \\
\text { Setelah Ibu } \\
\text { Melahirkan, ASI } \\
\text { Tidak Keluar }\end{array}$} & \multicolumn{2}{|c|}{ Normal } & \multicolumn{2}{|c|}{ Stunting } \\
\hline & \multirow[b]{2}{*}{$\mathrm{n}$} & \multirow[t]{2}{*}{$\%$} & & \multirow[t]{2}{*}{$\%$} \\
\hline & & & $\mathrm{n}$ & \\
\hline $\begin{array}{l}\text { Melakukan } \\
\text { perangsangan yaitu si } \\
\text { bayi didekatkan ke } \\
\text { putting untuk } \\
\text { mengisap (IMD) }\end{array}$ & 18 & 90,0 & 14 & 70,0 \\
\hline $\begin{array}{l}\text { Tanya ke } \\
\text { dokter/petugas } \\
\text { kesehatan }\end{array}$ & - & - & I & 5,0 \\
\hline $\begin{array}{l}\text { Langsung kasi susu } \\
\text { formula }\end{array}$ & 2 & 10,0 & 4 & 20,0 \\
\hline $\begin{array}{l}\text { Diberi madu, air } \\
\text { putih, dll }\end{array}$ & - & - & I & 5,0 \\
\hline Jumlah & 20 & 100 & 20 & 100 \\
\hline
\end{tabular}

Perangsangan IMD pada ibu yang mempunyai balita menunjukkan bahwa lbu balita melakukan perangsangan IMD ketika ASI tidak keluar yaitu sebanyak $90,0 \%$ pada ibu yang mempunyai status gizi balita normal dan $70,0 \%$ pada ibu yang mempunyai pada status gizi balita yang stunting. Sedangkan masih ada ibu balita stunting memberikan selain ASI pada saat ASI tidak Keluar yaitu sebesar $25,0 \%$.

ASI eksklusif diberikan sejak bayi lahir hingga berusia enam bulan. Selama periode tersebut, disarankan untuk hanya memberi ASI tanpa tambahan asupan apa pun. Hasil penelitian ini diperoleh data sebagai berikut:

Tabel V. Pemberian ASI Ekslusif Umur 0-6 Bulan

\begin{tabular}{lcccc}
\hline \multicolumn{1}{c}{$\begin{array}{c}\text { Pemberian ASI } \\
\text { Ekslusif }\end{array}$} & \multicolumn{2}{c}{ Normal } & \multicolumn{2}{c}{ Stunting } \\
\cline { 2 - 5 } & $\mathrm{n}$ & $\%$ & $\mathrm{n}$ & $\%$ \\
\hline ASI saja & 9 & 45,0 & 7 & 35,0 \\
\hline $\begin{array}{l}\text { ASI dan lainnya } \\
\text { (susu formula, }\end{array}$ & $\mathrm{II}$ & 55,0 & 13 & 65,0 \\
$\begin{array}{l}\text { tajin, madu, air } \\
\text { putih) }\end{array}$ & & & & \\
\hline \multicolumn{1}{c}{ Jumlah } & 20 & 100 & 20 & 100 \\
\hline
\end{tabular}

Pemberian ASI saja sampai dengan usia 6 bulan dalam penelitian ini dapat dijelaskan bahwa, jumlah terbanyak yaitu sampel yang mendapat ASI saja sampai dengan usia 6 bulan sebanyak 45,0\% pada balita status gizi normal sedangkan $35,0 \%$ pada balita status gizi stunting.

\section{Pola Konsumsi}

Pemberian Makanan Pendamping-Air Susu Ibu(MP-ASI) diberikan dengan cara yang responsif (responsive feeding), artinya pemberian MP-ASI ini harus konsisten sesuai sinyal lapar dan kenyang. Walaupun diberikan dengan cara yang responsif, pemberian MP-ASI tetap perlu jadwal yang teratur, yaitu dua kali makanan kecil di antaranya, dengan waktu makan tidak boleh lebih dari 30 menit. Hasil penelitian ini diperoleh data sebagai berikut:

Tabel VI. Frekuensi Pemberian Makanan PendampingAir Susu Ibu (MP-ASI) Dalam Sehari

\begin{tabular}{lcccc}
\hline \multicolumn{1}{c}{$\begin{array}{c}\text { Frekuensi } \\
\text { Pemberian } \\
\text { MP-ASI }\end{array}$} & \multicolumn{2}{c}{ Normal } & \multicolumn{2}{c}{ Stunting } \\
\cline { 2 - 5 } & $\mathrm{n}$ & $\%$ & $\mathrm{n}$ & $\%$ \\
\hline $\begin{array}{l}\text { Tidak tentu } \\
\text { memberikan MP- } \\
\text { ASI }\end{array}$ & $\mathrm{I} 6$ & 80,0 & $\mathrm{I7}$ & 85,0 \\
\hline I kali & - & - & $\mathrm{I}$ & 5,0 \\
\hline 2 kali & 2 & 10,0 & $\mathrm{I}$ & 5,0 \\
\hline 3 kali & 2 & 10,0 & $\mathrm{I}$ & 5,0 \\
\hline \multicolumn{1}{c}{ Jumlah } & 20 & 100 & 20 & 100 \\
\hline
\end{tabular}

frekuensi pemberian MP-ASI sebagian besar tidak menentu frekuensi memberikan MP-ASI yaitu sebesar $80,0 \%$ pada balita normal dan $85,0 \%$ balita stunting. Frekuensi pemberian MP-ASI sebanyak 2-3 kali dengan persentase $10 \%$, pada balita normal dan sebesar $5 \%$ pada balita stunting.

Secara umum, pemberian makan balita adalah tiga kali makanan utama (pagi, siang, sore) dan dua kali makan selingan (di antara dua kali makan utama). Berikut data hasil penelitian ini adalah:

Tabel VII. Frekuensi Pemberian makan anak Dalam Sehari

\begin{tabular}{lcccc}
\hline \multirow{2}{*}{$\begin{array}{c}\text { Frekuensi } \\
\text { Pemberian makan }\end{array}$} & \multicolumn{2}{c}{ Normal } & \multicolumn{2}{c}{ Stunting } \\
\cline { 2 - 5 } & $\mathrm{n}$ & $\%$ & $\mathrm{n}$ & $\%$ \\
\hline$<3$ kali & 7 & 35,0 & 9 & 45,0 \\
\hline 3 kali & 9 & 45,0 & 7 & 35,0 \\
\hline$>3$ kali & 4 & 20,0 & 4 & 20,0 \\
\hline \multicolumn{1}{c}{ Jumlah } & 20 & 100 & 20 & 100 \\
\hline
\end{tabular}

Ferkuensi pemberian makan dalam sehari menunjukkan bahwa ibu memberikan makan anak sebanyak 3 kali 
dalam sehari pada balita normal $45 \%$, sedangkan pada balita stunting terbesar $<3$ kali yaitu $45 \%$.

Proses perkembangan dan pertumbuhan anak berjalan optimal, bagi balita sangat membutuhkan asupan gizi yang seimbang dan sesuai dengan usianya. Asupan gizi seimbang akan terpenuhi jika makanan yang kita konsumsi sehari-hari mengandung jumlah dan jenis zat gizi yang sesuai dengan kebutuhan tubuh. Berdasarkan hasil penelitian ini dapat diuraikan sebagai berikut:

Tabel IX. Makanan Yang Diberikan Selalu Memenuhi Syarat Gizi Seimbang

\begin{tabular}{|c|c|c|c|c|}
\hline \multirow{2}{*}{$\begin{array}{c}\text { Makanan Yang } \\
\text { diberikan } \\
\text { Memenuhi } \\
\text { Syarat Gizi } \\
\text { Seimbang }\end{array}$} & \multicolumn{2}{|c|}{ Normal } & \multicolumn{2}{|c|}{ Stunting } \\
\hline & $\mathrm{n}$ & $\%$ & $\mathrm{n}$ & $\%$ \\
\hline $\begin{array}{l}\text { Ya (makanan } \\
\text { pokok + lauk pauk } \\
+ \text { sayur + buah- } \\
\text { buahan) }\end{array}$ & 6 & 30,0 & - & - \\
\hline Kadang-kadang & 9 & 45,0 & 8 & 40,0 \\
\hline Tidak pernah & 5 & 25,0 & 12 & 60,0 \\
\hline Jumlah & 20 & 100 & 20 & 100 \\
\hline
\end{tabular}

Makanan yang diberikan oleh ibu menunjukkan makanan balita dengan status gizi normal kadangkadang memenuhi syarat gizi seimbang yaitu $45,0 \%$, sedangkan makanan balita dengan status gizi stunting tidak pernah memenuhi syarat gizi seimbang yaitu $60,0 \%$.

\section{Higienis Pribadi Dan Lingkungan}

Akses terhadap air bersih dan fasilitas sanitasi yang buruk dapat meningkatkan kejadian penyakit infeksi yang dapat membuat energi untuk pertumbuhan teralihkan kepada perlawanan tubuh menghadapi infeksi, zat gizi sulit diserap oleh tubuh dan terhambatnya pertumbuhan. Pada penelitian ini sarana air bersih sampel dapat diuraikan sebagai berikut:

Tabel X. Sarana Air Bersih

\begin{tabular}{lcccc}
\hline \multirow{2}{*}{ Sarana Air Bersih } & \multicolumn{2}{c}{ Normal } & \multicolumn{2}{c}{ Stunting } \\
\cline { 2 - 5 } & $\mathrm{n}$ & $\%$ & $\mathrm{n}$ & $\%$ \\
\hline Tidak ada & 2 & 10,0 & 10 & 50,0 \\
\hline $\begin{array}{l}\text { Ada, bukan milik } \\
\text { sendiri, berbau, }\end{array}$ & & & 3 & 15,0 \\
\hline
\end{tabular}

\begin{tabular}{|c|c|c|c|c|}
\hline $\begin{array}{l}\text { berwarna dan } \\
\text { berasa }\end{array}$ & & & & \\
\hline $\begin{array}{l}\text { Ada, milik sendiri, } \\
\text { berbau, berwarna } \\
\text { dan berasa }\end{array}$ & - & - & - & - \\
\hline $\begin{array}{ll}\text { Ada, bukan } & \text { milik } \\
\text { sendiri, } & \text { tidak } \\
\text { berbau, } & \text { tidak } \\
\text { berwarna, } & \text { tidak } \\
\text { berasa } & \end{array}$ & 5 & 25,0 & I & 5,0 \\
\hline $\begin{array}{l}\text { Ada, milik sendiri, } \\
\text { tidak berbau, } \\
\text { tidak berwarna, } \\
\text { tidak berasa }\end{array}$ & 13 & 65,0 & 6 & 30,0 \\
\hline Jumlah & 20 & 100 & 20 & 100 \\
\hline
\end{tabular}

kepemilikan sarana air bersih yang digunakan, persentase terbesar pada lingkungan balita dengan status gizi normal yaitu ada, milik sendiri, tidak berbau, tidak berwarna dan tidak berasa yaitu $65,0 \%$, sedangkan pada balita dengan status gizi stunting yaitu $30,0 \%$, serta yang tidak ada memiliki sarana air bersih yaitu sebesar $50,0 \%$.

Keberadaan sarana pembuangan sampah yang tidak memenuhi standar berpotensi memicu timbulnya penyakit infeksi karena higiene dan sanitasi yang buruk (misalnya diare dan kecacingan) yang dapat menganggu penyerapan zat gizi pada proses pencernaan. Berdasarkan data penelitian diperoleh hasil sebagai berikut:

Tabel XI. Sarana Pembuangan Sampah

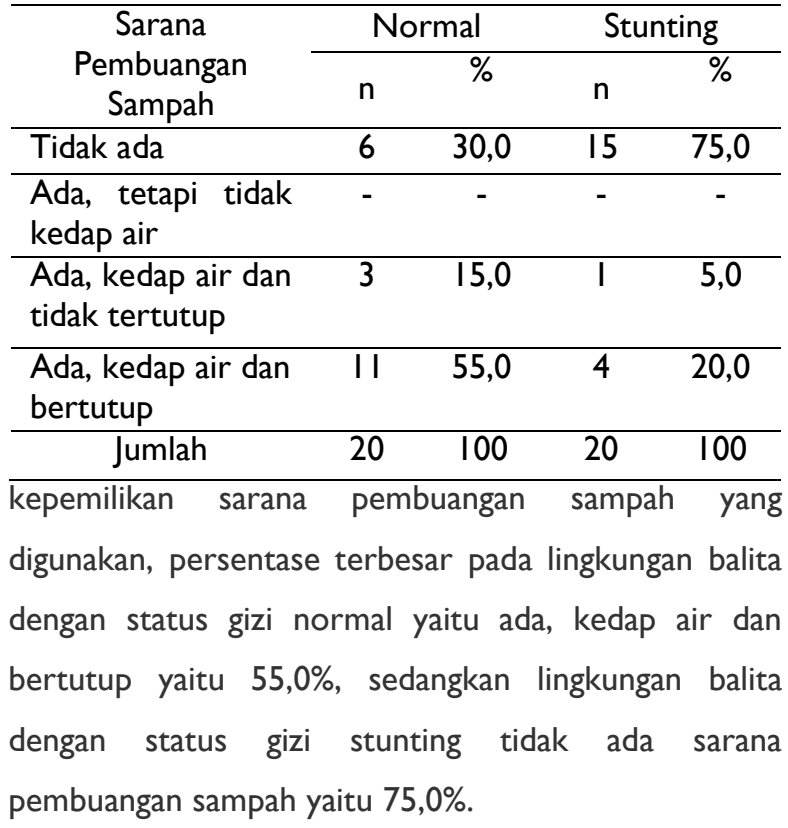




\section{PEMBAHASAN}

\section{Pola Asuh}

Pemberian ASI eksklusif memiliki banyak sekali kandungan nutrisi yang sangat bermanfaat bagi kesehatan dan tumbuh kembang anak. Sementara di Indonesia, pemberian ASI eksklusif masih menjadi tantangan tersendiri karena beredar banyak mitos dikalangan masyarakat. Cukup banyak ibu yang akhirnya tidak memberikan ASI secara eksklusif selama 6 bulan kepada anaknya karena terpengaruh dari mitos-mitos tersebut. Berdasarkan beberapa penelitian, ASI eksklusif mampu meningkatkan kelangsungan hidup anak yang berkaitan dengan perkembangan tubuhnya sehingga dapat terhindar dari wasted dan stunting. Dalam memenuhi kebutuhan gizi anak, ibu harus memberikan ASI secara eksklusif sampai 6 bulan dan hingga anak berumur 2 tahun ibu tetap bisa terus memberikan ASI dan untuk memenuhi kebutuhan gizinya harus diberikan makanan tambahan lainnya yang sesuai dengan kebutuhan usianya (Naini dkk, 2020).

Persentase penilaian pemberian ASI yang pertama kali keluar (kolostrum), untuk kelompok balita status gizi normal dan status gizi stunting sama. Pada persentase penilaian, bila dalam beberapa jam setelah ibu melahirkan, ASI tidak keluar, ibu melakukan, perangsangan IMD ialah sebesar 20,0\%. Persentase penilaian pertama kali Ibu balita yang memberikan ASI setelah melahirkan pada balita status gizi normal sebesar $75,0 \%$ dan balita status gizi stunting $70,0 \%$, selebihnya ibu balita yang memberikan selain ASI saat setelah melahirkan. Hal ini dikarenakan ASI yang belum keluar.

Ibu-lbu balita ketika usia balita 0-6 bulan sudah memberikan makanan lain selain seperti susu formula, tajin, madu dan air putih. Hal ini terjadi pada kelompok balita status gizi normal $55 \%$ dan balita status gizi stunting $65 \%$. Saat ibu tidak berdampingan dengan bayi ASI diganti dengan susu formula.
Menurut MCA (20I5) Faktor ketiga yang dapat menyebabkan stunting adalah pemberian ASI (Air Susu Ibu) yang salah, karena inisiasi yang terlambat, tidak ASI eksklusif, dan penghentian penyusuan yang terlalu cepat. Asumsi peneliti, masih tingginya angka balita tidak mendapatkan ASI eksklusif dikarenakan pengetahuan ibu balita yang kurang, serta ibu balita selain sebagai ibu rumah tangga, juga membantu perekonomian keluarga sehingga harus bekerja dan meninggalkan anaknya.

\section{Pola Konsumsi}

Tahap awal dari kekurangan zat gizi dapat diidentifikasi dengan penilaian konsumsi pangan. Konsumsi pangan yang kurang akan berdampak terhadap kurangnya zat gizi dalam tubuh (Bappenas, 2018). Penilaian pola konsumsi, jika dilihat awal balita diberikan makanan tambahan selain ASI, pada kelompok balita status gizi normal dan status gizi balita stunting sama yaitu persentase terbesar pada usia anak 6 bulan. Namun, persentase terbesar saat ini anak tidak mendapatkan MP-ASI yaitu pada kedua kelompok. Alasan terbesar ibu balita tidak memberikan anaknya MP-ASI ialah ketidaktahuan ibu tentang MP-ASI yakni terbesar pada kelompok balita stunting $75,0 \%$, sehingga makanan yang diberikan pada anak sama dengan makanan seharihari yang disediakan di rumah tangga.

Tingkat pertumbuhan berbeda untuk setiap anak, begitu juga dengan kebutuhan energinya. Tingkat pertumbuhan untuk usia I sampai 3 tahun dan 7 sampai 10 tahun lebih cepat, sehingga mengharuskan kebutuhan energi yang lebih besar (Fitri,20I2).

Untuk pemberian makan anak dalam sehari juga terdapat perbedaan kedua kelompok, pada kelompok balita dengan status gizi normal persentase terbesar ibu balita memberikan makan 3 kali sehari sedangkan, kelompok balita dengan status gizi stunting persentase terbesar ibu balita memberikan makan $<3$ kali sehari. $\mathrm{Hal}$ ini disebabkan cara pemberian makan yang dilakukan ibu balita, pada balita normal persentase 
terbesar dengan disuapi, sedangkan persentase terbesar pada balita stunting tidak disuapi.

Namun, untuk penilaian waktu pemberian makan dan jenis makanan yang diberikan pada balita status gizi normal dan status gizi stunting menunjukkan hasil yang sama besar yaitu tidak pernah teratur dan kadangkadang berbeda tiap kali makan. Lain hal nya dengan penilaian makanan yang diberikan memenuhi syarat gizi seimbang, persentase terbesar balita status gizi normal kadang-kadang memenuhi syarat gizi seimbang dan balita status gizi stunting tidak pernah memenuhi syarat gizi seimbang. Dan jika dilihat bagaimana reaksi anak saat diberikan makan, persentase terbesar balita normal menunjukkan reaksi senang sebesar $80,0 \%$ sedangkan balita stunting hanya 50,0\%. Hal ini juga berpengaruh terhadap sisa makanan yang diberikan, pada balita dengan status gizi normal persentase terbesar nya yaitu dihabiskan sedangkan, balita stunting kadang-kadang dihabiskan.

Menurut Septriasa (20I2), anak balita pada usia I-3 tahun bersifat konsumen pasif, konsumen pasif artinya pada usia I-3 tahun makanan yang dikonsumsi tergantung pada apa yang disediakan oleh ibu.

Selain itu, sikap ibu balita juga mempengaruhi anak jika tidak mau makan, persentase terbesar pada balita status gizi normal dan status gizi stunting sama yakni dengan cara membujuk dan membiarkan. Asumsi peneliti, masih kurangnya pola konsumsi balita di masyarakat tepian sungai Kapuas Tanjung Hilir disebabkan pengasuhan yang kurang optimal.

Anggota keluarga yang mengasuh balita tidak membiasakan anak makan dengan baik, yaitu makan dengan teratur 3 kali sehari serta keragaman jenis makanan yang kurang dan memenuhi syarat gizi seimbang. Selain itu, pada balita stunting anak dibiarkan makan sendiri/tidak disuapi, sehingga makanan tidak pernah dihabiskan.

\section{Higienis Pribadi Dan Lingkungan}

Hygiene Perorangan (Personal Hygiene) adalah menjaga kebersihan diri sebelum dan sesudah beraktivitas. Sedangkan sanitasi lingkungan ialah kebersihan lingkungan, Menurut Hasan dan Kadarusman (2019) hygiene dan sanitasi lingkungan memegang peranan penting bagi tumbuh kembang anak.

Kebersihan perorangan yang kurang akan memudahkan terjadinya penyakit-penyakit kulit dan saluran pencernaan seperti diare dan cacingan. Sedangkan kebersihan lingkungan erat hubungannya dengan penyakit saluran pernafasan, saluran pencernaan, serta penyakit akibat nyamuk. Oleh karena itu penting membuat lingkungan menjadi layak untuk tumbuh kembang anak sehingga meningkatkan rasa aman bagi ibu atau pengasuh anak dalam menyediakan kesempatan bagi anaknya untuk mengeksplorasi lingkungan.

lingkungan yang sehat perlu diupayakan dan dibiasakan Lingkungan sehat terkait dengan keadaan bersih, rapi dan teratur. Oleh karena itu, anak perlu dilatih untuk mengembangkan sifat-sifat sehat seperti, mandi 2 kali sehari, cuci tangan sebelum dan sesudah makan, akan teratur 3 kali sehari, menyikat gigi sebelum tidur dan buang air kecil pada tempatnya / WC (Hafid, F., \& Djabu, U, 2018).

Pada penelitian kali ini menunjukkan bahwa persentase terbesar yang diasuh oleh anggota keluarga sama pada kedua kelompok balita normal dan stunting. Persentase terbesar memandikan anak dan menggunakan sabun juga sama pada kedua kelompok. Sedangkan, menggosok gigi menunjukkan perbedaan bahwa pada kelompok balita normal persentase terbesar lebih atau 2 kali sehari, dan pada kelompok balita stunting persentase terbesar tidak pernah menggosok gigi.

Namun untuk memotong kuku, persentase terbesarnya sama pada kedua kelompok yaitu seminggu sekali. Dan untuk kebiasaan menggunakan alas kaki/sandal saat bermain keluar rumah menunjukkan hasil yang berbeda, yaitu untuk kelompok balita normal kadang-kadang menggunakan 
alas kaki sebesar $50 \%$ dan $35 \%$ selalu menggunakan alas kaki, sedangkan kelompok balita stunting kadangkadang menggunakan alas kaki sebesar $85 \%$.

Untuk penilaian sanitasi lingkungan atau kebersihan lingkungan di wilayah Tepian Sungai Kapuas Tanjung Hilir, menunjukkan lingkungan yang tidak sehat. Hal ini dibuktikan dengan tidak ada sarana air bersih dan sarana pembungan sampah pada kelompok balita stunting, sedangkan kelompok balita normal ada memiiliki sarana air bersih, milik sendiri sebesar $65 \%$, dan $25 \%$ ada tetapi bukan milik sendiri dan sarana pembuangan sampah yang kedap air dan tertutup. Untuk kepemilikan jamban kedua kelompok sama-sama mempunyai jamban, leher angsa dan septic tank. Selain itu, wilayah Tepian Sungai Kapuas Tanjung Hilir juga tidak memiliki sarana pembuangan air limbah pada kelompok balita normal dan stunting sehingga tergenang tidak teratur di halaman dan parit-parit kecil/selokan.

Hal ini sejalan dengan MCA (20I5), yang mengemukakan bahwa faktor lingkungan rumah juga mempengaruhi kejadian stunting berupa stimulasi dan aktivitas anak yang tidak adekuat, perawatan yang kurang, sanitasi dan pasukan air yang tidak adekuat, akses dan ketersediaan pangan yang kurang, alokasi makanan dalam rumah tangga yang tidak sesuai, dan edukasi pengasuh yang rendah. Selain itu, penyebab stunting adalah makanan komplementer yang tidak adekuat, yang dibagi menjadi tiga, yaitu kualitas makanan yang rendah, cara pemberian yang tidak adekuat, dan keamanan makanan dan minuman. Kualitas makanan yang rendah dapat berupa kualitas mikronutrien yang rendah, keragaman jenis makanan yang dikonsumsi dan sumber makanan hewani yang rendah, makanan yang tidak mengandung nutrisi, dan makanan komplementer yang mengandung energi rendah. Cara pemberian yang tidak adekuat berupa frekuensi pemberian makanan yang rendah.

\section{KESIMPULAN}

I. Berdasarkan hasil penelitian yang telah dilakukan menunjukkan bahwa tidak ada perbedaan pola asuh pada kedua kelompok, yakni kelompok balita normal dan stunting.

2. Pemberian makan anak dalam sehari juga terdapat perbedaan kedua kelompok, pada kelompok balita dengan status gizi normal persentase terbesar ibu balita memberikan makan 3 kali sehari sedangkan, kelompok balita dengan status gizi stunting persentase terbesar ibu balita memberikan makan $<3$ kali sehari.

3. Penilaian sanitasi lingkungan atau kebersihan lingkungan di wilayah Tepian Sungai Kapuas Tanjung Hilir, menunjukkan lingkungan yang tidak sehat.

\section{UCAPAN TERIMA KASIH}

Terima kasih kami sampaikan kepada seluruh civitas akademika dan Jurusan Gizi Poltekkes Kemenkes Pontianak yang telah membantu terlaksananya penelitian ini.

\section{REFERENSI}

I. Badan Penelitian Dan Pengembangan Kesehatan Kementerian Kesehatan RI, Laporan Hasil Riset Kesehatan Dasar (Riskesdas) 2018, Jakarta.

2. Badan Penelitian Dan Pengembangan Kesehatan Kementerian Kesehatan RI, Laporan Hasil Riset Kesehatan Dasar (Riskesdas) 2010, Jakarta.

3. Badan Penelitian Dan Pengembangan Kesehatan Kementerian Kesehatan RI, Laporan Hasil Riset Kesehatan Dasar (Riskesdas) 2013, Jakarta.

4. Ummi Kalsum dan Abas Basuni Jahari. 2015, Strategi Menurunkan Prevalensi Gizi Kurang Pada Balita Di Provinsi Jambi. JMJ, vol. 3, No.l, hal 4559, Mei 2015.

5. Naini dkk, (2020). The Relationship Between Exclusive Breastfeeding Practice And The Phenomenon Of Wasting (Malnutrition) And Stunting In Leran Village, Bojonegoro, Indonesia. International Journal of Psychosocial 
Rehabilitation, ISSN:1475-7I92, Volume 24(9): 2692-2699.

6. MCA Indonesia. 2015. Stunting dan Masa Depan Indonesia.http://mca-indonesia.go.id/wp-

content/uploads/2015/0I/Backgrounder-StuntingID.pdf.

7. Bappenas, 2018. Pembangunan Gizi Indonesia Kajian Sektor Kesehatan. Direktorat Kesehatan Dan Gizi Masyarakat, Kedeputian Pembangunan Manusia, Masyarakat Dan Kebudayaan, Kementerian Perencanaan Pembangunan Nasional/Badan Perencanaan Pembangunan Nasional.

8. Fitri. 2012. Berat Lahir sebagai Faktor Dominan Terjadinya Stunting pada Balita (12-59 bulan) di Sumatera (Analisis Data Riskesdas 2010). Fakultas Kesehatan Masyarakat Program Studi IImu Kesehatan Masyarakat Universitas Indonesia Depok.

9. Septriasa. 2012. Hubungan antara Pola Asuh dengan Status Gizi Balita di Desa Tatelu Kecamatan Dimembe Kabupaten Minahasa Utara. jurnal kesehatan. I2(2): I55.

10. Amrul Hasan, Haris Kadarusman. 2019. Akses ke Sarana Sanitasi Dasar sebagai Faktor Risiko Kejadian Stunting pada Balita Usia 6-59 Bulan. Jurnal Kesehatan. Volume 10, Nomor 3, November 2019. ISSN 2086-775I (Print), ISSN 2548-5695 (Online).

II. Hafid, F., \& Djabu, U. (2018). Efek Program SBABS Terhadap Pencegahan Stunting Anak Baduta di Kabupaten Banggai dan Sigi. Indonesian Journal of Human Nutrition, 4(2), 79-87.

12. Nasikhah, R.,\& Margawati, A. (20/2) Faktor kejadian stunting pada balita usia 24-36 bulan di Kecamatan Semarang Timur. Journal of Nutrition College, I(I): 7I5-730. 